\title{
A Comparison of the Peers Method and Traditional Methodologies, and Risk Behaviors in Studies of the Prevalence of Drug Consumption in a Population of Female, Chilean Students
}

\author{
Jorge Rodríguez T. ${ }^{1}$, Ana Maria Fernández ${ }^{2}$, Macarena Valdés C. ${ }^{1}$, \\ Enrique Hernández A. ${ }^{1}$, Sergio Ramírez P. ${ }^{1}$, and América Román Q. ${ }^{1}$ \\ ${ }^{1}$ Universidad de Chile (Chile) \\ ${ }^{2}$ Universidad de Santiago de Chile (Chile)
}

\begin{abstract}
The present study investigates drug consumption and risk behaviors among female students between 8 th and 12th grade in two communities in the city of Santiago, Chile. Based on studies of university populations, we hypothesize that the students' reports of their consumption of licit drugs will tend to be consistent with their actual use of said drugs using two methods to investigate consumption, while their consumption of illicit drugs will be susceptible, and will tend to be under-reported when evaluated through traditional self-report measures. In order to compare the two methods, a cross-sectional study was designed that would compare reported drug consumption, first using the peers method, and then by means of traditional self-report in a group of 350 students. The results show that women's reports of licit drug consumption converge using the two methods, while as earlier suggested, women's illicit drug consumption was found to be under-reported when traditional methodologies were used.
\end{abstract}

Keywords: peers method, drug consumption, students, women

Este estudio investiga el consumo de drogas y los comportamientos de riesgo de alumnas entre los $8^{\circ}$ y $12^{\circ}$ cursos en dos comunidades de la ciudad de Santiago, Chile. Empleando dos métodos para investigar el consumo, y basándonos en los estudios de poblaciones universitarias, hipotetizamos que los autoinformes de las alumnas sobre su consumo de drogas legales tenderán a ser consistentes con el uso real de dichas drogas, mientras que su consumo de drogas ilícitas será susceptible y tenderán a infra-informar de ello cuando se evalúa a través de medidas tradicionales de autoinforme. Para comparar los dos métodos, se diseñó un estudio transversal que compararía el consumo informado, primero empleando el método de pares, y después por medio del autoinforme tradicional, en un grupo de 350 alumnas. Los resultados muestran que los informes de las chicas sobre su consumo de drogas legales convergen empleando los dos métodos, mientras que, como se ha sugerido, infra-informaban sobre su consumo de drogas ilegales cuando se empleaban metodologías tradicionales.

Palabras clave: método de pares, consumo de drogas, alumnas, mujeres

Correspondence concerning this article should be addressed to Jorge Rodríguez T., Independencia 939, Escuela de Salud Pública, Facultad de Medicina, Universidad de Chile, FAX: 7774163. E-mail: jrodrigu@med.uchile.cl and jrodrigu80@ hotmail.co

How to cite the authors of this article: Rodríguez, J., Fernández, A.M., Valdés, M., Hernández, E., Ramírez, S. and Román, A. 
Nowadays, drug addiction is a problem of national concern and one that crosses borders (CONACE, 2005). In Latin America, drug consumption is a regional priority because each day there exist more and more young drug addicts, which indicates that this phenomenon is growing, and that it has come to affect both institutions and societies at large (Florenzano, 1998; Florenzano, Valdés, Serrano, Rodríguez, \& Roizblatt, 2001; Loas et al., 2005; Mc Whinter \& Florenzano, 1998; Nishimura, Hishimuna, Else, Goebert, \& Andrade, 2005; Rees \& Valenzuela, 2003).

In Chile, a great number of studies on this subject have been conducted that show the magnitude of drug consumption, especially those directed by the National Committee for the Control of Narcotics (CONACE). This organization has been conducting studies at the national, regional and municipal levels for over 10 years to evaluate the magnitude, size and tendencies of the many drug problems that affect the general, as well as student populations (CONACE, 1996-2005).

The results of this last, national study by CONACE, the organization's sixth survey about student drug use, shows the comparative magnitude of the three studies of student populations (CONACE, 2005). In the period from 2001 to 2005, where illicit drug consumption is concerned, crack stands out as the greatest concern (a global increase from $2.2 \%$ to $2.6 \%$ ). Illicit drug consumption has experienced an increase from $18.2 \%$ to $20.4 \%$, an increment that is due primarily to the increase in crack consumption among women, which reached $28.6 \%$, while the men's consumption increased by $10 \%$. No less worrisome is the case of marijuana consumption, which grew $3.4 \%$ during the same period, and whose global level of consumption has reached $15.2 \%$, up from the $14.7 \%$ reported during the previous period. Based on these indicators, there has been a noticeable, rapid increase in consumption to the extent that one in every five students in $8^{\text {th }}-12^{\text {th }}$ grade consumes marijuana. Reported rates of consumption show that in men and women, there were $4.5 \%$ and $2.2 \%$ increases, respectively, during that period. In monthly marijuana consumption, on the other hand, women showed an increase close to $2 \%$ and men a decrease of $8.8 \%$.

According to CONACE's findings (2005), as far as annual consumption of licit drugs, tobacco use dropped $4.2 \%$ due to a decrease in consumption by both men and women. With regards to monthly consumption (which is associated with actual, present consumption), however, consumption was reported to be rather similar in the two periods with a rate of $42 \%$. As was also found on reports of annual consumption, women's consumption was greater than men's (45.3\% and $38.5 \%$, respectively). Annual alcohol consumption was at $60.2 \%$, having decreased $2.4 \%$ since 2001, while alcohol consumption done in the last 30 days increased rather considerably, by $11.8 \%$; this was tremendously affected by the $14.1 \%$ increase in women's alcohol consumption and a $9 \%$ increase in men. Also, the frequency of consumption and the quantity consumed are considerably on the rise. In fact, $11.7 \%$ of the students that consume alcohol report that when they drink, they consume at least five drinks.

Rodríguez, Hernández, and Cumsille (2005), using alternative research methodologies to investigate drug consumption, have obtained higher rates than those found in studies conducted using traditional methodologies (such as those used by CONACE). For example, in a sample of 142 young, university students with an average age of 21.5 years old, the rate of licit drug consumption in the last year (tobacco and/or alcohol) had reached $92.3 \%$ in women and $92.0 \%$ in men, a slight difference that, nevertheless, was not found to be statistically significant (Rodríguez et al., 2005). However, it was observed that women's smoking habit had become significantly higher than men's, $87.5 \%$ and $73.3 \%$, respectively.

Regarding alcohol consumption, Rodríguez et al.'s (2005) estimated rates are worrisome as found in both genders, and no statistically significant differences were found between them $76.8 \%$ in men and $82.6 \%$ in men). In another study that employed the same methodology (Rodríguez, Fernandez, Hernández, \& Ramírez, 2006), a 400-person sample was formed of youths ranging from 18 to 26 years of age (with a mean of 21.4 years old). The indexes of consumption were rather similar to those found in the previously mentioned study, with licit drug consumption in the last year at $94.5 \%$. Tobacco consumption had reached $73.5 \%$ and alcohol consumption $89.7 \%$, and in women, tobacco consumption was at $75 \%$ and alcohol consumption at $86.2 \%$. On the whole, monthly consumption of licit drugs in women was $73.8 \%$ for tobacco use and $80.8 \%$ for alcohol consumption, very similar to the findings for annual consumption, which indicates the stability of these measures of licit drug use.

Evaluating the possible effects and consequences to which a high prevalence of drug consumption could lead, the relationship between drug consumption and antisocial behavior has been evaluated at the local level, and it has been found that among marijuana users, one in every four young people has participated in a street fight in the last year, which is a significantly higher rate than that of those that do not consume marijuana (Rodríguez et al., 2006). Similarly, among the women that reported having consumed tobacco in the last year, $16.9 \%$ have participated in street fights, $4.8 \%$ has attempted suicide and in $86.7 \%$, those events occurred during the last year. In addition, within this group of women, $8.4 \%$ reports having participated in street fights and $1.8 \%$ has attempted suicide during the last month, which shows that their risky behaviors have increased. In other words, if an annual projection of these monthly rates were made, $21.6 \%$ would attempt suicide and $100 \%$ would participate in street fights during the coming year, which means that maladaptive behaviors are on the rise. The situation for women that report having consumed alcohol in the last month is rather similar to the group of female 
tobacco consumers, which verifies the need to attend to the increase in this type of behavior in women. Related to these gender differences in the consumption and effects of addictive substances is a study carried out at the international level by the National Council for Narcotic and Psychotropic Substance Control (CONSEP). It was conducted on students between the ages of 14 and 19 years old, and showed that in Spain, more women than men consume alcohol, tobacco and sedatives, and that the frequency of consumption of other psychoactive substances is almost as high in women as in men (CONSEP, 1999). This pattern of consumption is beginning to appear in other developed countries, too, where it has been observed that those three substances are more widely consumed by women than men. This tendency for women to smoke more than men was found to occur in approximately $15-20$ of the countries evaluated (Galves Sánchez, 2003).

Furthermore, in the United States, surveys have shown that boys' and girls' rates of alcohol consumption between the ages of 12 and 17 years old were similar for the first time in the early 1990's. Also, in the United States, women are beginning to drink at a younger and younger age (García \& González, 2002).

Recent studies on drug consumption among Sao Paolo university students show that licit drug consumption has risen in women, but that excessive consumption still tends to be greater in men ( $86.5 \%$ for tobacco and $65 \%$ for alcohol). On the other hand, over the last five years, a strong relationship has been found between drug consumption, violence and victimization (Pillon, O'Brien, \& Piedra, 2005). In a recent study in Spain, Caballero, Carrera, Muñoz, and Sánchez (2007) showed that ambivalent attitudes may be a predictor for risky behaviors such as excessive alcohol consumption in youths. Also, in a study in Bangkok by Ruangkanchanasetr, Plitponkarnpim, Hetrakul, and Kongsakon (2005), it was found that $37.8 \%$ of adolescents consume illicit drugs, while tobacco consumption is at $5.4 \%$ and alcohol consumption at $37.3 \%$. A comparison of the prevalence of drug consumption in university-level medical students in developed countries showed that their cigarette smoking decreased (from $28.8 \%$ to $9.2 \%$ ) in striking contrast to their strong increase in alcohol consumption (Boland et al., 2006). As far as drug consumption in Chile, alcoholism has become a major concern, and it afflicts young people with increasing force. These studies confirm and demonstrate that the problem of drug addiction and its consequences on the world, and particularly on our country, is far from being resolved. On the contrary, it continues to worsen and expand to younger and younger populations, and that has been supported by specialized literature on both illicit and licit drugs.

For example, a national study was recently completed that studied the behavior of licit drug consumption in students in $4^{\text {th }}$ to $7^{\text {th }}$ grade in the communities of Recoleta and Huechuraba in the Metropolitana Region of Chile. It was found that in a sample of 234 students (with an average age of 11.5 years old), annual consumption of licit drugs was: $18.6 \%$ for tobacco and $16 \%$ for alcohol. Also, monthly consumption was found to be $9.7 \%$ for tobacco and $6.2 \%$ for alcohol, and the age at which participants began smoking was 11.1 years old. Finally, the age at which participants began to consume alcohol was 11.7 years old, on average, and consumption of illicit drugs was reported as being 3.5\% during that year (Rodríguez et al., in press).

Based on the findings above, we may assert that the antecedents to the problem of drug consumption, as described in scientific papers written on the topic, are far from being resolved, in the world and in our country in particular. As was mentioned in the literature review of the present study, everyday, more women are adapting risky behaviors that were traditionally associated with the masculine sex and in fact, recent studies have shown that quite early in childhood, women present more external behaviors than their male counterparts (Esparó, Canals, Torrente, \& Fernandez-Ballart, 2004). Specifically, alcoholism afflicts women with an increasing force at an early age (García \& González, 2002). As far as illicit drug consumption goes, generally speaking, no great gender differences have been observed and anymore, differences in drug consumption are best observed in terms of their magnitude and frequency (Rodríguez, Hernández \& Fernandez, 2007).

An additional point that warrants further study and attention is the underreporting of consumption (especially in the case of illicit drugs). Studies of the general population tend to under-represent individuals whose consuming behavior is legally or socially-sanctioned (Wiebel, 1990). Along those lines, a great number of strategies have been developing since the late 1980's and early 1990's that allow hidden populations to be identified (Fountain \& Griffiths, 1999; Griffiths, Gosop, Powis, \& Strang, 1993). The Privileged Access Interview method (EAP), created by Kluebler and Hausser (1997), is that which has been most widely studied, and most widely accepted in Europe. In our country, there are also applications of this method (Santis et al., 2002, 2004a, $2004 \mathrm{~b}, 2007)$ where information is re-collected by interviewers who have Privileged Access to subjects that exhibit the behavior that the study has targeted. Aside from that one, another similar method has been developed that is specifically oriented toward reducing the under-reporting of drug consumption in the general population, known as the peers method, wherein students serve as interviewers for their peers or classmates. It is generally used in populations where there is some suspicion that underreporting is an issue, in other words, when there is a hidden population (see details in Rodríguez et al., 2005, 2006, 2007).

All of the aforementioned research confirms that licit drug consumption, and especially the magnitude of alcohol 
consumption, has been growing steadily among young people and is beginning at younger and younger ages. At the same time, women have been incorporated not only into drug consumption, but have come to adopt some of the risky behaviors associated with it. For that reason, it is extremely relevant to estimate the actual, present consumption of drugs among women, especially at an early age, and to have the highest possible level of certainty that underreporting of consumption is minimized.

To synthesize, this study aims to evaluate drug consumption and its associated, risky behaviors in a female, student population using a new method that aims to reduce underreporting of drug consumption.

The hypothesis upon which the present study is based is that reporting of drug consumption is associated with acceptance on the part of consumer society, and that for that reason, it is necessary to consider adequate methods that reduce underreporting. It is because of this that illicit drug consumption reports would be better when gathered via the peers method than by means of traditional methodologies. Last, in the case of licit drug consumption, it is hypothesized that there will be no difference found between the two methods.

\section{Method}

The present study had a transverse design and the evaluations were all done at once, using a student sample gathered from all establishments that accepted participation.

\section{Participants}

The population was composed of female students in $8^{\text {th }}$ $-12^{\text {th }}$ grade that attend public and/or subsidized schools in the communities of Recoleta and Huechuraba, which are lower-middle and middle class areas. The sample was formed between 2005 and 2006. During that time, indexes of licit and illicit drug consumption were evaluated, utilizing two parallel methods of data collection.

The minimum sample size was 296 female students, 148 of whom were evaluated using the peers method and 148 through traditional methodologies, which found the greatest level of licit drug consumption in this population, $94.5 \%$, with a $95 \%$ level of confidence and a maximum error of the estimate of $5.2 \%$ (the estimated potency being $50 \%)$. The final sample was composed of 350 students, $18 \%$ greater than expected, and 193 students were evaluated using traditional methodologies while 157 were assessed using the peers method, which translates to a higher level of confidence and/or precision with $55.5 \%$ being evaluated through traditional methodologies and $44.5 \%$ using the peers method. The average age for both groups was 14.4 years old with a standard deviation of 1.5 years.

\section{Procedure}

Four schools were selected within these communities that were convenient for the purposes of the study, and they were randomly assigned methods, making sure that indexes of the vulnerability of the schools were similar in order to guarantee the homogeneity of the sample.

In schools where the peers method was applied, the following steps were followed to select the evaluators:

1. In grades 8 through 12 , informational meetings were held about the study, soliciting the voluntary participation of the students; such was the case for both interviewers and interviewees.

2. The objectives of the study were explained in detail to the students, all of whom were voluntarily recruited to participate in the interview, and after each was separately interviewed, the students were selected based on their completion of certain requirements. For example, they were not to discriminate either against or in favor of drug consumers.

3. The six students who were selected to be interviewers (two from one school and four from another) were trained to apply the interview, independently of the school they attended.

In the first student interviewers' training session, the objectives of the study were explained once again, as was the instrument to be used and the type of application. The importance of the study, anonymity, the need for all information to be kept confidential, and the privacy of all procedures were emphasized, highlighting the importance that the interviews be conducted in places where the participants would feel comfortable. In the second and third sessions, the interviewers were given the instrument themselves, playing both the roles of interviewer and interviewee (role-playing).

The total number of students was calculated for each school. The interviewers were supervised by the researchers during the entirety of the process of data collection, maintaining constant communication and resolving any doubts that arose.

In the two remaining schools, traditional methodologies were applied, which consisted of filling out and submitting self-report questionnaires.

Using traditional methodologies, we worked with four, experienced interviewers for each school, and they came from outside the selected schools. In each session, the interviewers informed participants of the objectives and instructions of the study aloud, emphasizing the anonymity and confidentiality of the information that they would submit, and later giving the instrument to each student to respond to individually. Once the questionnaire was finished, the students returned the instruments to their respective interviewers, who then thanked them for participating and returned to the classroom. 
Variables, Instruments and Data Analysis

Tobacco and alcohol were considered to be the licit drugs studied, while the illicit drugs were marijuana, cocaine, crack, ecstasy or another substance. A smoker was considered to be someone who consumes tobacco at least twice per week; alcohol or marijuana consumption implied that they be consumed at least once per week. For the rest of the drugs (cocaine, ecstasy, crack or other), the criterion was that they were consumed at least once per month.

Evaluation in the case of both methods used an instrument validated by Rodríguez and Hernández (2005) to measure drug consumption. This instrument was designed to evaluate three constructs or factors, with confidence intervals estimated as: Soft Drug Consumer: 0.77; Hard Drug Consumer: 0.68; Crimes and Beliefs: 0.62, which together explain $78.3 \%$ of the observed variance.

The construct of "Soft Drugs" aims to measure licit drug consumption and marijuana consumption; as far as "Hard Drugs," this measures consumption of illicit drugs excluding marijuana; and the factor "Crimes and Beliefs" measures antisocial behaviors and attitudes such as fights and street fights, suicide attempts and religious beliefs.

Once the information was collected, the data was entered into SPSS, where a descriptive analysis was done to review the information in terms of central tendency and distribution. Also, intervals of bilateral and unilateral confidence were constructed of $95 \%$.

In order to compare the means (frequency of consumption) at a global level, using both methods, of both licit and illicit drugs, and of each individually, a statistical t-test or a MannWhitney test was done for each student, as a function of the normality and variability necessary for the test.

In the case of qualitative variables, such as consumption of licit and illicit drugs, either the proportional difference (Z) test or Fisher's exact test was done. For all analyses, an alpha value less than or equal to .05 was considered statistically significant.
Results

\section{Drug Consumption}

At the global level, it was observed that at least one in every two students consumes at least one, licit drug $(51.85 \%)$. The data gathered through traditional means about drug consumption during a period of one year (within the last year) showed that $51.1 \%$ of the students had consumed at least one licit drug. That value was $52.6 \%$ when collected via the peers method. However, that difference was not considered significant $(Z=0.2898, p=.772)$, which was similar to the case of actual, present consumption, where $31.9 \%$ of the students interviewed through traditional methodologies reported consumption and $32.7 \%$ of those interviewed with the peers method reported consumption. That difference did not qualify as being statistically significant $(Z=0.1462, p=.884)$.

In comparing tobacco use in the last year using both methods, no statistically significant differences were found. Actual, present tobacco consumption (in the last 30 days) also showed no difference between the two methods (see Table 1).

Regarding alcohol consumption, one may see that in Table 2, the differences between the annual and monthly rates, by type of methodology, were not significant.

As may be seen in Tables 3 and 4, when comparing annual and monthly consumption of illicit drugs, significant differences were found between methods. Also, it was observed that for more common drugs, such as marijuana (THC), cocaine and crack, reporting of consumption was higher through the peers method than when traditional methodologies were used. However, in spite of these differences in reporting, statistically significant differences were not found how less widely consumed drugs (ecstasy and other inhalants, see Table 3) were reported. Data on illicit drug consumption in the last 30 days showed that

Table 1

Frequency and Percentages of Female Tobacco Consumption in the Two Communities Evaluated, by Type of Method

\begin{tabular}{lccccccc}
\hline Period of Consumption & TM & PM & Total & $N$ & Z Test & $p$-Value & Effect of design \\
\hline Last year & $80(42 \%)$ & $66(43 \%)$ & $146(43 \%)$ & 342 & 0.2449 & .4033 & 0.9992 \\
Last 30 days & $47(25 \%)$ & $40(26 \%)$ & $87(25 \%)$ & 344 & 0.3256 & .3726 & 0.9999 \\
\hline
\end{tabular}

Note $. \mathrm{TM}=$ Traditional methodology, $\mathrm{PM}=$ Peers method.

Table 2

Frequency and percentages of female alcohol consumption in the two communities evaluated, by type of methodology

\begin{tabular}{lccccccc}
\hline Period of Consumption & TM & PM & Total & $N$ & Z Test & $p$-Value & Effect of design \\
\hline Last year & $76(40 \%)$ & $53(35 \%)$ & $129(38 \%)$ & 344 & 0.9800 & .1635 & 1.0012 \\
Last 30 days & $33(17 \%)$ & $26(17 \%)$ & $59(17.2 \%)$ & 344 & 0.0700 & .4721 & 1.0015 \\
\hline
\end{tabular}

Note TM $=$ Traditional methodology, $\mathrm{PM}=$ Peers method. 
marijuana, independent of the method used to collect data, was the most prevalent. As Table 4 shows, during this period, statistically significant differences were obtained between the two methods for the consumption of both marijuana and crack.

Finally, the actual, present consumption of illicit drugs in students is $10.2 \%$, representing $66.7 \%$ of the annual rate, which shows that consumption is both high and on the rise. The same consumption evaluated through the peers method was $14.7 \%$ and only $7 \%$ through traditional methodologies, a difference that does achieve statistical significance $(Z=2.356, p=.009)$. As for annual consumption, $21 \%$ of students reported that they consume illicit drugs using the peers method, while $11 \%$ did so through traditional methodologies, and that difference, too, was significant.
In comparing annual and monthly consumption of illicit drugs, statistically significant differences were found in the reported consumption gleaned through the two methods (see Table 5).

\section{Risk Behaviors}

With respect to the risk behavior of having participated in street fights within the last year, the relationship between scores using the two methods is approximately a ratio of one to three, $21.4 \%$ and $34.8 \%$, respectively, for TM and MP. For the period of the last month, this relationship was one to five, $12.8 \%$ reporting consumption via the peers method and only $4.9 \%$ reporting it through traditional methodologies, which was a significant difference (see Figure 1).

Table 3

Percentage of Actual, Present, Illicit Drug Consumption by Females in the Two Communities Evaluated, by Type of Methodology

\begin{tabular}{lcrrrr}
\hline Type of drug consumed in the last year & TM & PM & Z Test & $p$-Value & Effect of design \\
\hline Marijuana & 8.4 & 18.9 & $2.8644 * *$ & $.0021^{*}$ & 0.9817 \\
Cocaine & 2.1 & 7.1 & $2.2399 * *$ & $.0127 *$ & 0.9885 \\
Crack & 1.6 & 5.7 & $* * *$ & $.0400^{*}$ & 0.9930 \\
Ecstasy & 1.6 & 2.8 & $* * *$ & .3380 & 1.0002 \\
Other inhalant & 3.7 & 4.6 & $0.4243 * *$ & .4510 & 1.0016 \\
\hline
\end{tabular}

Note. $\mathrm{TM}=$ Traditional methodology, $\mathrm{PM}=$ Peers method.

$* p<.05, * *$ a $\mathrm{z}$ - test was done, $* * *$ a Fisher Exact Test $(Z)$ test was done.

Table 4

Percentage of Actual, Present, Illicit Drug Consumption by Females in the Two Communities Evaluated, by Type of Methodology

\begin{tabular}{|c|c|c|c|c|c|}
\hline Type of drug consumed in the last month & $\mathrm{TM}$ & $\mathrm{PM}$ & $\mathrm{Z}$ Test & $p$-Value & Effect of design \\
\hline Marijuana & 4.2 & 14.2 & $3.26512 * *$ & $.0006 *$ & 0.9800 \\
\hline Cocaine & 1.6 & 4.3 & $* * *$ & .1260 & 0.9922 \\
\hline Crack & 1.0 & 5.0 & $* * *$ & $.0340 *$ & 0.9901 \\
\hline Ecstasy & 2.1 & 1.3 & $* * *$ & .5680 & 1.0016 \\
\hline Other inhalant & 3.7 & 4.6 & $* * *$ & .4510 & 1.0015 \\
\hline
\end{tabular}

Note. $\mathrm{TM}=$ Traditional methodology, $\mathrm{PM}=$ Peers method.

$* p<.05, * *$ a $\mathrm{z}$ - test was done, $* * *$ a Fisher Exact Test $(Z)$ test was done.

Table 5

Frequency and Percentage of Illicit Drug Consumption among Women, by Type of Method

\begin{tabular}{lccccccc}
\hline Period of Consumption & TM & PM & Total & $N$ & Z Test & $p$-Value & Effect of design \\
\hline Last year & $21(11 \%)$ & $30(21 \%)$ & $51(15.2 \%)$ & 335 & 2.4815 & $.006 *$ & 0.9793 \\
Last 30 days & $13(7 \%)$ & $21(15 \%)$ & $34(10 \%)$ & 334 & 2.3563 & $.009 *$ & 0.9963 \\
\hline
\end{tabular}

Note. $\mathrm{TM}=$ Traditional methodology, $\mathrm{PM}=$ Peers method .

$* p<.05$. 


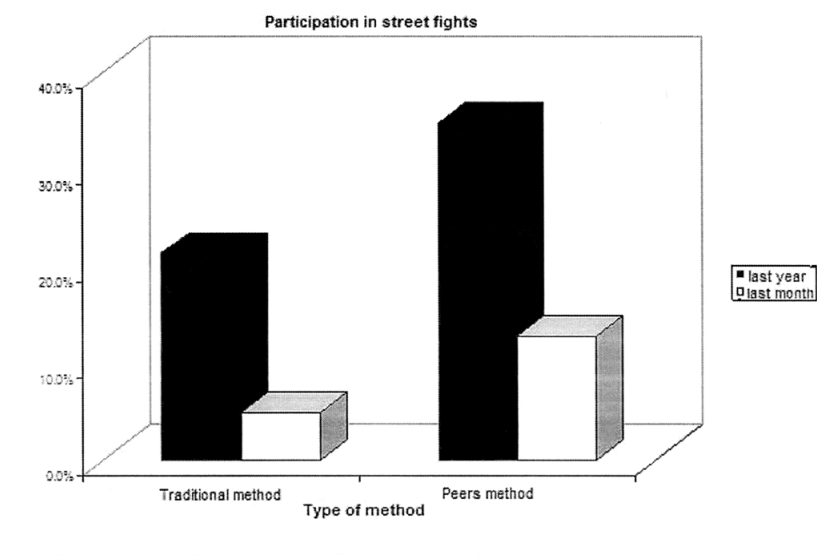

Note: $Z=4.700, p=.000$ for in the last year; $Z=4.460, p=.000$ for in the last month

Figure 1. Percentage of participants that report participation in street fights as found by the two methods.

Among those who have smoked during the last year, the peers method found the average age at which they had begun smoking to be similar to that found through traditional measures. Also, the number of times per week that the interviewees reported smoking was equal. Meanwhile, the average weekly number of cigarettes smoked was significantly different for the two methods (see Table 6).

As may be seen in Table 7, for alcohol consumers, the average age at which participants reported beginning to drink was slightly lower using the peers method than traditional methodologies, yet this difference fell short of achieving statistical significance. Also, the average number of drinks consumed during one week was similar for both methods. This was also true of the average number of times they drink per week.

\section{Discussion}

International studies have demonstrated that drug consumption is concentrated in the younger age groups of the population (18 to 25 years of age). Chile's case is similar, but illicit drug consumption is found to occur in a broader age range, one that extends from 14 to 35 years old.

This warrants that the central concern of studies of national drug use focus primarily on these age groups. Also, research has indicated that rates of drug consumption have increased in women, becoming comparable to, and in the case of tobacco consumption even surpassing, men in their consumption, although it is still indicated that men continue to surpass female consumption in both quantity and frequency.

The results of the present study have demonstrated that the consumption of licit drugs among female students, independent of the type of drug used, rate, quantity and frequency of consumption, are similar when evaluated using the peers method and traditional methodologies. That finding is consistent with the hypothesis that for drugs whose consumption is socially acceptable, under-reporting does not occur. However, in the case of illicit drug consumption in female students, where there are social and/or legal repercussions to that behavior, under-reporting makes it important to compare reports through the two methods, since the prevalence of consumption obtained using the peers method is higher than that obtained through traditional methodologies (and this also occurs for some types of illicit drugs such as marijuana, crack and cocaine).

It is relevant to note that the quantity and frequency of consumption, both for licit and illicit drugs, are no different for the two methods. In fact, Age at onset, frequency and

Table 6

Characteristics Associated with Female Consumption of Tobacco, by Type of Methodology

\begin{tabular}{|c|c|c|c|c|c|c|}
\hline & $\mathrm{TM}$ & & $\mathrm{PM}$ & & Statistical test & $p$-Value \\
\hline Age at onset & 12.5 & 1.8 & 12.9 & 1.7 & $1.31 * *$ & .096 \\
\hline Average number of times consumed per week & 4.0 & 3.5 & 4.5 & 2.3 & $0.78 * *$ & .434 \\
\hline Average number of cigarettes consumed per week & 7.1 & 9.9 & 26.6 & 21.7 & $5.99 * * *$ & $.000 *$ \\
\hline
\end{tabular}

Note. $\mathrm{TM}=$ Traditional methodology, $\mathrm{PM}=$ Peers method.

$* p<.05, * *$ a $t$ - test was done, *** a Mann-Whitney $(Z)$ test was done.

Table 7

Characteristics Associated with Female Alcohol Consumption, by Type of Method

\begin{tabular}{|c|c|c|c|c|c|c|}
\hline & $\mathrm{TM}$ & & $\mathrm{PM}$ & & Statistical test & $p$-Value \\
\hline Age at onset & 13.1 & 2.2 & 12.8 & 1.3 & $1.005^{*}$ & .159 \\
\hline Average number of drinks consumed per week & 2.8 & 3.8 & 2.4 & 1,6 & $0.557 * *$ & .578 \\
\hline Average number of times alcohol is consumed per week & 2.0 & 3.1 & 1.7 & 0.7 & $1.206^{* *}$ & .228 \\
\hline
\end{tabular}

Note. $\mathrm{TM}=$ Traditional methodology, $\mathrm{PM}=$ Peers method .

$* p<.05, * *$ a $t$ - test was done, *** a Mann-Whitney $(Z)$ test was done. 
quantity of consumption of crack were actually higher when measured by traditional methodology than when the peers method was applied. This leads us to believe that for those female students that dare to report their consuming behavior through traditional methodologies, they do not hide the magnitude of their consumption, which further affirms the hypothesis of this study.

The high prevalence of drug consumption in female students found in the present research study coincides with the findings of other studies. This national tendency also coincides with the rates of consumption found to occur in female university students in Sao Paulo (Pillon et al., 2005).

One of the primary questions that arise from the results of this study is whether or not the indexes of consumption obtained through the peers method would be replicable in other populations. A great limitation to the use of this research method is that it is applicable only when peer interviewers are available, in other words, when the population to be interviewed identifies their interviewers as peers; this is the case for populations considered to be closed.

In agreement with the results obtained about illicit drug consumption in women, we may affirm that the indexes found through the peers method were not only greater than those found when traditional measures were employed, but also in other, national studies (see, for example, CONACE, 2005).

These results suggest the need to implement the peers method soon. It has been validated as a tool that at the very least reduces under-reporting of illicit drug consumption, if not altogether eliminating it.

To conclude, the results found in the present study suggest that maybe this new method should continue to be applied in samples of older age groups and in different student, regional, socioeconomic and school groups, etc.

\section{References}

Boland, M., Fitzpatrick, P., Scallan, E., Daly, L. \& Herity, B., Horgan, J., \& Bourke, G. (2006). Trends in medical student use of tobacco, alcohol and drugs in an Irish university, 19732002. Drug and Alcohol Dependence, 85, 123-128.

Caballero, A., Carrera, P., Muñoz, D., \& Sánchez, F. (2007). Emotional ambivalence in risk behaviors: The case of occasional excessive use of alcohol. The Spanish Journal of Psychology, 10, 151-158.

Consejo Nacional de Control de Sustancias Estupefacientes y Psicotrópicas (CONSEP) (1999). Informe $\mathrm{N}^{\circ} 2$, Observatorio Español Sobre Drogas. [Electronic version]. Available at: http://www.pnsd.msc.es/categoria2/publica/pdf/oed-2.pdf

Consejo Nacional para el Control de Estupefacientes (CONACE) (1996). Segundo estudio nacional de drogas en la población general de Chile. Santiago: CONACE.

Consejo Nacional para el Control de Estupefacientes (CONACE) (1997). Segundo estudio nacional de drogas en la población escolar de Chile. Santiago: CONACE.
Consejo Nacional para el Control de Estupefacientes (CONACE) (1998). Tercer estudio nacional de drogas en la población general de Chile. Santiago: CONACE.

Consejo Nacional para el Control de Estupefacientes (CONACE) (1999). Tercer estudio nacional de drogas en la población escolar de Chile. Santiago: CONACE.

Consejo Nacional para el Control de Estupefacientes (CONACE) (2000). Cuarto estudio nacional de drogas en la población general de Chile. Santiago: CONACE.

Consejo Nacional para el Control de Estupefacientes (CONACE) (2001). Cuarto estudio nacional de drogas en la población escolar de Chile. Santiago: CONACE.

Consejo Nacional para el Control de Estupefacientes (CONACE) (2002).Quinto estudio nacional de drogas en la población general de Chile. Santiago: CONACE.

Consejo Nacional para el Control de Estupefacientes (CONACE) (2003). Quinto estudio nacional de drogas en la población escolar de Chile. Santiago: CONACE.

Consejo Nacional para el Control de Estupefacientes (CONACE) (2004). Sexto estudio nacional de drogas en la población general de Chile. Santiago: CONACE.

Consejo Nacional para el Control de Estupefacientes (CONACE) (2005). Sexto estudio nacional de drogas en la población escolar de Chile. Santiago: CONACE.

Esparó, G., Canals, J., Torrente, M., \& Fernández-Ballart, J. D. (2004) Psychological problems and associated factors at 6 years of age: Differences between sexes. The Spanish Journal of Psychology, 7, 53-62.

Florenzano, R. (1998). El adolescente y sus conductas de riesgo. Santiago de Chile: Ediciones Universidad Católica de Chile.

Florenzano, R., Valdés, M., Serrano, T., Rodríguez, J., \& Roizblatt, A. (2001). Desarrollo yoico, familia y adolescencia. Revista Psiquiatría y Salud Mental, 18, 34-40.

Foutain, J., \& Griffiths, P. (1999). Synthesis of qualitative research on drug use in European Union: Report on an EMCDDA proyect. European Addiction Research, 5, 4-20.

Galves Sánchez, J. (2003). Prevención del consumo de tabaco, alcohol y drogas.

[Electronic version]. Available at: http://www.vv.es/previnfad/pdfs/previnfad-drogas.pdf

García A., L., \& González G., M. T. (2002). Consumo de sustancias en chicas adolescentes. Comisión de drogodependencia y adicciones. [Electronic version]. Available at: http://www.cop.es/delegaci/palmas/biblio/drogod/drogo05.pdf

Griffiths, P., Gosop, M., Powis, B. \& Strang, J. (1993). Reaching hidden populations of drug users by privileged access interviewers: Methodological and practical issues. Addictions, $88,1617-1626$.

Kluebler, D., \& Hausser, D. (1997). The Swiss hidden population study: Practical and methodological aspects of data collection by privileged access interviewers. Addiction, 92, 325-334

Loas, G., Guilbaud, O., Peréz-Diaz, F., Verrier, A., Stephan, P., Lang, F., Bizouard, P., Venisse, J., Corcos, M., Flament, M., \& Jeammet, P (2005). Dependency and suicidality in addictive disorders. Psychiatry Research, 137, 1103-111. 
Mc Whinter, M., \& Florenzano, R.(1998). Correlatos psicosociales de la farmacología: Resultados de un estudio en Santiago de Chile. Revista Psiquiátrica, 15, 10-22.

Nishimura, T, Hishinuma, E., Else, I., Goebert, E., \& Andrade, N. (2005). Ethnicity and adolescent substance use. Cultural Diversity and Ethnic Minority Psychology, 11, 239-258.

Pillon, S., O'Brien, B., \& Piedra, K. (2005). The relationship between drugs use and risk behaviours in Brazilian university students. Revista Latino-Americana Enfermagem, 13, 11691176.

Rees, R. \& Valenzuela, A. (2003). Características individuales y de la estructura familiar de un grupo de adolescentes abusadores de alcohol y/o marihuana. Revista Chilena de Neuro-psiquiatria, 41, 173-186. [Electronic version]. Available at: http://www.scielo.cl/scielo.php?script=sci_arttext\&pid=S0717922 $72003000300002 \& \operatorname{lng}=$ es\&nrm=iso

Rodríguez, J., Fernández, A. M, Hernández, E., \& Ramírez, S. (2006). Conductas agresivas, consumo de drogas e intentos de suicidios en jóvenes universitarios. Terapia Psicológica, 24, 63-69.

Rodríguez, J., Fernández, A. M., Hernández, E, Valdés, M., Pérez, V., \& Ramírez, S. (in press). Estudio de prevalencia del consumo de drogas en escolares de $4^{\circ}$ a $7^{\circ}$ básico.

Rodríguez, J., \& Hernández, E., (2005). Análisis de la confiabilidad y validez de constructo de un instrumento que mide el consumo de drogas lícitas e ilícitas en estudiantes universitarios. Terapia Psicológica, 23, 83-90.

Rodríguez, J., Hernández, E. \& Cumsille, M. A. (2005). Implementación de la metodología de pares para estimar el consumo de drogas lícitas e ilícitas. Revista Chilena de Salud Pública, 9, 20-24.

Rodríguez, J., Hernández, E., \& Fernández, A. M. (2007). Descripción del consumo de drogas lícitas e ilícitas entre género a través de la metodología de pares. Revista Médica de Chile, 135, 449-459.

Ruangkanchanasetr, S., Plitponkarnpim, A., Hetrakul, P., \& Kongsakon, R. (2005). Youth risk behavior survey: Bangkok, Thailand. Journal of Adolescent Health, 36, 227-235.
Santis, R., Hayden, V., Ruiz, S., Anselmo, E., Anuch, C., Bronstein, E., Osorio, J., Toledo, O., Torres, R., \& Pérez de los Cobos, J. (2002). Privileged access interviewing to characterize cocaine base paste (CBP) users. Proceedings from the $64^{\text {th }}$ Annual Scientific Meeting of the College on Problems of Drug Dependence. Quebec, Canada. Drug and Alcohol Dependence 66: s155. Available at: http://biopsych.com:81/CPDD02_Web/ MeetProgAbSearch_02.html

Santis, R., Hidalgo, C.G., Hayden, V., Anselmo, E., Ruiz, S., Rodríguez, J., Torres, R., Cartagena, F., Pérez, M., \& Saint John's, C. (2004a) Risk behaviors of out-of-treatment cocaine base paste users and cocaine hydrochloride users: A cohort study by means of privileged access interviewers. Proceedings from the $66^{\text {th }}$ Annual Scientific Meeting of the College on Problems of Drug Dependence. San Juan, Puerto Rico. Available at: http://biopsych.com:81/CPDD04_Web/MeetProg AbSearch_04.html

Santis, R., Hayden, V., Ruiz, S., Anselmo, E., Torres, R., \& Pérez de los Cobos, J. (2004b). Implementación de la entrevista de Acceso privilegiado para caracterizar usuarios de pasta base de cocaína. Revista Chilena Neuro-psiquiatrica, 4, 273-280. Available at: http://www.scielo.cl/scielo.php?script=sci_arttext\&pid= S071792272004000400004\&lng=es\&nrm=iso

Santis, R., Hidalgo, C.G., Hayden, V., Anselmo, E., Rodríguez, J., Cartagena, F., Dreyse, J., \& Torres, R. (2007). Consumo de sustancias y conductas de riesgo en consumidores de pasta base de cocaína no consultantes a servicios de rehabilitación. Revista Médica de Chile, 135, 45-53.

Weiner, M., Sussman, S., Sun, P., \& Dent, C. (2005). Explaining the link between violence perpetration, victimization and drug use. Addictive Behaviors, 30, 1261-1266.

Wiebel, W. (1990). Identifying and gaining access to hidden populations. NIDA Research Monographs 98, 4-11.

Received July 30, 2007

Revision received April 15, 2008 Accepted May 10, 2008 